\title{
STRUCTURED, TRANSITIONAL AND UNSTRUCTURED CIVIL SOCIETIES: AN INSTITUTIONAL APPROACH
}

\author{
RUBÉN MÉNDEZ REATEGUI*
}

Fecha de recepción: 31 de julio de 2014.

Fecha de aceptación: 3 de noviembre de 2014.

\section{I \\ INTRODUCTION}

This paper seeks to introduce an alternative conceptual taxonomy of civil society as an input to Austrian law and economics and neoinstitutional economics. The conceptual framework of the paper develops three categories: unstructured, transitional, and structured civil societies. This categorization was, in part, inspired by Parsons' (1966, p. 33) contribution to functional sociology: «Society is an intelligent structure, rationally structured to integrate its complex parts into a coherent whole (...) A social system consists of a plurality of social agents interacting with each other in a situation which has at least a physical or environmental aspect, agents motivated by a tendency towards the "optimization of satisfaction" whose interactions with their own circumstances, are defined and influenced by a culturally shared system of structured symbols.»

However, our proposal does not focus on the associative system as a «set» of aggregates (Parsons, 1968). ${ }^{1}$ In contrast, following a previous academic paper (Mendez, 2013), the individuality of

* (MQU, UCM y USAL): miembro del staff académico del Departamento de Economía de la Universidad de Macquarie. Además posee estudios en Derecho y CCPP por la UNMSM, un M.A. en Economía por la UNED, un M.A. en Economía de la Escuela Austriaca y un MSc. en Instituciones y Desarrollo Económico por la URJC y un MSc. en Análisis Económico y Políticas Públicas por la USAL.

1 In Parsons' theory, «associative action» is nothing more than an effort to obey or follow institutions or rules (1968). However, methodological subjectivism and 
the agents is assumed. This differs from Parsons' approach (1978), where agents become secondary receivers in the process of socialization. In addition, it has been assumed in this paper that the permanent display of individualism (economic subjectivism) in civil society occurs through the interaction of associative agents (Garcia-Guadilla et al., 1997). These individuals acting as "creative or entrepreneurial agents» (Kirzner, 1978a) help to maintain associative cohesion through productive entrepreneurship (Baumol, 1990).

Therefore, our proposal relates to the following idea: it is individuals who permanently affect the evolution of associative structures and civil society as a whole. This is important because civil societies within this evolutionary process are affected by complex events (Hayek, 1978; Zanotti, 1981; Potts, 2000) ${ }^{2}$ and changes that are very difficult to identify from mainstream perspectives in $\mathrm{Neo}$ Institutional economics and Law and Economics (San Emeterio, 2006). Thus, it is essential to selectively use previous approaches to understand civil societies as functional structures where the role of the individual is key and therefore cannot be implicitly assumed (Polanyi, 1974; Kirzner, 1978a; Huerta de Soto, 2006; Foss et al., 2010).

As this paper attempts to bring together a large but disparate body of research topics in a more coherent research agenda (Zanotti, 2004; Heyne et al., 2009; Boettke, 2012), it has been organized into three main sections. The first section examines the idea of associative structures, which relate to our alternative conceptual taxonomy of civil society. The second section engages with the idea that a theoretical illustration of civil society "also» represents an evolutionary process, a perspective «inspired» by the

individualism are avoided and clearly criticized. In addition, cultural phenomena (involving associative action) such as ideas, ideals, goals and norms can be considered as causally relevant elements in approaches influenced by Parsons' theory. Even though this author never abandoned the idea of individual choice constrained by external forces, he turned away from the focus on consciousness and associative action presented in his primary contribution «The Structure of Social Action».

${ }^{2}$ Hayek is also considered as one of the fathers of Complex Systems Theory. In this regards, complex system theorists very often refer to Hayek's 1978 essay «The Results of Human Action not of Human Design». 
Theory of Spontaneous Order as developed by Hayek (1960) and Barry (1982). The third section discusses the purpose of an alternative taxonomy and conceptual proposal of civil societies and introduces apreliminary attempt to implement a categorization, after which a set of conclusions is submitted.

II ASSOCIATIVE STRUCTURES AND CIVIL SOCIETIES

The idea of associative structures and civil societies, despite referring to many different types of collective groups, does not deny the existence of specific scenarios. These specific scenarios describe and classify certain moments that reflect the complex evolution of civil societies and associative structures (Krause, 2007). This is so because even civil societies and associative structures, described by Ostrom (1990) as micro and macro communities, regard collectiveness as a dynamic environment that is not self-contained, and whose members need to meet individual requirements before collective ones (Hayek, 1948). This dynamic environment might be described as a sustainably organized scenario or the category of structured civil society.

Therefore, interest shown in an approach that could be described as structurally functionalist lies in assuming the existence of four primary subsystems or associative structures in a civil society (Parsons, 1966). These structures refer to the functions that can be fulfilled within them (see Figure 1).

Our theoretical illustration takes from «Parsons» Functionalism' the idea that there are functional imperatives. Functional

Figure 1

STRUCTURES IN A CIVIL SOCIETY AND ITS FUNCTIONS

Adaptation

Ability to achieve goals

\begin{tabular}{|l|l|}
\hline System of trust & Societal/Community rules \\
\hline Economic aspects & Political aspects \\
\hline
\end{tabular}

Integration

Latency 
imperatives are comprised of a complex set of activities, directed towards satisfying one or more functions of the four primary subsystems in a civil society. It is generally assumed that there are four functional imperatives and that, in order to survive, a primary subsystem must perform these four functions: 1) Adaptation: Any system must meet any external situational demands. It must adapt to its environment and adapt the environment to its needs; 2) Ability to achieve goals: Any system must define and achieve their ultimate goals; 3 ) Integration: Any system must regulate the interaction between its constituent parts. It must also control the ratio between the other three functional requirements; 4) Latency or pattern maintenance: Any system must provide, maintain and renew the motivation of individuals (and any cultural patterns that create and maintain this motivation).

As evident from Figure 1, these four structures are related to: a) Economic aspects, which play the role of adapting civil society to the associative environment through activities such as work, production and distribution - thus, the economy adapts the environment to the needs of civil society, and helps civil society adapt to these external realities; b) Political aspects (or a political system) that perform the function of achieving goals through the pursuit of associative targets and the transfer of individuals and resources to that end; c) A system of trust (for example, families), which refers to the transmission of culture (associative norms or values) to other people so that they internalize them; d) Organizational or societal communityrules (e.g. the law), traditionally used to coordinate and facilitate the interaction between various components of civil society. ${ }^{3}$

${ }^{3}$ In recent years, it has been argued that there are multiple types of set of interactions among individuals (Ostrom, 1990). These sets of interactions may also describe as «deliberately arranged» (e.g. communal property). Such interactions allow coordination within a framework of private property. This fact introduces social scenarios where individuals freely (contractually) decide to participate or abandon. 


\section{III CIVIL SOCIETY}

A comprehensive analysis of these structures or subsystems is not the aim of this paper. Instead, this paper seeks to integrate the Parsonian functional approach in a general, unspecific way, so that we can avoid any potential limitations in understandingcivil society, in part, as an «evolutionary process». That is to say, avoiding any arguments that advocate cultural determinism or a historicist analysis of the evolution of associative groups (Acemoglu et al., 2012).

This fundamental reason, where a civil society represents an evolutionary process, follows a perspective inspired by the Theory of Spontaneous or Self Organization Order in the same way as that developed by Hayek ${ }^{4}$ (1960, pp. 39-40 and 1978, p. 38): «(...) If social phenomena showed no order except in so far as they were consciously designed, there would indeed be no room for theoretical sciences of society and there would be, as is often argued, only problems of psychology. It is only in so far as some sort of order arises as a result of individual action but without being designed by any individual that a problem is raised, which demands a theoretical explanation. But although people dominated by the scientistic prejudice are often inclined to deny the existence of any such order (and thereby the existence of an object for theoretical sciences of society).»

«(...) One effect of our habitually identifying order with a made order or taxis is indeed that we tend to ascribe to all order certain properties which deliberate arrangements regularly, and which respect to some of these properties necessary, possess. Such orders are relatively simple or at least necessarily confined to such moderate degrees of complexity as the maker can still

4 «Catallaxy» as Hayek uses the term refers to spontaneous order in civil society. This paper seeks to acknowledge the existence of spontaneous order and study it $e x$ post. Nevertheless, our taxonomy of civil societies cannot be fully described as a model of spontaneous order, despite being influenced by some of its main characteristics. Therefore, our target is less ambitious and consists of the introduction of a theoretical illustration or conceptual model through the use of this theory. 
survey; they are usually concrete on the sense just mentioned that their existence can be intuitively perceived by inspection; and, finally, having been made deliberately, they invariably do (or at one time did) serve a purpose of the maker. None of these characteristics necessarily belong to a spontaneous order or kosmos. Its degree of complexity is not limited to what human mind can master. Its existence need not manifest itself to our senses but may be based on purely abstract relations, which we can only mentally reconstruct. And not having been made it cannot legitimately be said to have a particular purpose, although our awareness of its existence may be extremely important for our successful pursuit of a great variety of different purposes.»

See also Norman Barry's view (1982, p. 9): «(...) it is concerned with those regularities in society, or orders of events, which are neither (1) the product of deliberate human contrivance (such as a statutory code of law or a dirigiste economic plan) nor (2) akin to purely natural phenomena (such as the weather, which exists quite independently of human intervention). While the words conventional and natural refer, respectively, to these two regularities, the "third realm," that of social regularities, consists of those institutions and practices which are the result of human action but not the result of some specific human intention.»

Consequently, this taxonomy of civil societies will consider, in part, one of the main aspects of a spontaneous order: unintended and unpredictable evolution. This is important because spontaneous order is frequently an unintended consequence of human actions, as it emerges as a result of individuals trying to meet their own ends. ${ }^{5}$ However, to some extent, though not entirely,

${ }^{5}$ Hayek also referred to spontaneous orders as «complex orders» or «kosmos». This is an important contrast with what this author called «simple orders» or «taxis». This latter category correlates with a modern definition of formal institutions or rules as developed by North (1991). This paper deals with the categorization of civil societies, which in part relates to the analysis of complex order or kosmos. However, the paper recognises that «coordinates groups» are not only an example of spontaneous interactions among individuals. In fact, some groups in their «ideal representation» (e.g. private companies) may also represent an example of «deliberate order». Ronald Coase extensively discussed this finding in his paper «The nature of the firm» (1942). Since this contribution, private companies may be defined as a "group of contracts». 
this approach has to be «balanced». In recent years, authors such as Elinor Ostrom (1990) have successfully argued that civil societies also show a set of interactions among individuals, which can be described as deliberately arranged (e.g. communal property). Such interactions allow coordination within a framework of private property. This fact introduces social scenarios -inside civil societieswhere individuals freely (contractually) resolve to participate or abandon.

IV

\section{THE PURPOSE OF THE TAXONOMY}

This paper introduces the following research question: To what extent can an alternative taxonomy of civil societies enhance the study of institutional coordination and, consequently, the modern economics of rules?

First of all, this is relevant because an alternative taxonomy would work alongside further studies to better the assessment of institutional coordination between both formal and informal rules and a comparative institutional analysis (Aoki, 2001). Further research for enhancing the assessment of institutional coordination is beneficial to advance studies in law and economics and new institutional economics (Mendez, 2013c). This is so, since the taxonomy considers that individuals have a propensity to seek associative synchronization or dynamic equilibriums (Huerta de Soto, 2010). Furthermore, it is compelled to share links and generate different degrees of voluntary cooperation and types of organization among civil society members (Ostrom et al., 2003). This process also requires a framework where interaction between formal and informal rules is functional (Cáceres, 2005). All this can be framed within a cultural and social cohesion. If this process is added to individual and group aspirations, it requires a degree of institutional stability that is achieved to the extent that the functional entrepreneurship and the political and economic environment point to a non-destructive competition context (Mendez, 2011).

Whilst a conceptual contribution, an alternative would represent a discernible point of departure,helping social science 
researchers to oversee and classify relevant variables affecting the economics of rules (Mendez, 2013a) and, consequently, from an institutional perspective, outcomes such as economic performance. In addition, in order to effectively achieve any of these tasks, core concepts, such as institutional weakening (Helmke \& Levitsky, 2004) and institutional coordination, might be considered. From this perspective, further analysis can also be introduced via the integration and assessment of studies based on proxies, such as interpersonal trust, institutional quality, perception of corruption, and the strengthening of property rights. ${ }^{6}$ Also, an understanding of these categorizations will be an important instrument for the aim of classifying civil societies as structure, transitional, and unstructured, according to their level of institutional weakening and institutional coordination.

This taxonomical approach might represent a balancing input. This is so, because despite extensive efforts to produce more analytical and empirical research that focuses on aggregate concepts such as institutional quality and the use of proxies (Acemoglu \& Johnson, 2005; Axala \& Fabro, 2008), scholars interested in mainstream law and economics and neo-institutional economics but with no formal economic training often have to contend with restrictions on important data, like statistics and econometrics (Alonso, 2008). Together with the issue of confronting paradigms (Kuhn, 1962; Zanotti, 1981), the existence of different degrees of rejection and acceptance of economic imperialism (Becker, 1962; Swedberg, 1990; Lazear, 2000; Maki, 2008), and the specific nature of each social science (Bullard \& McLean, 2002), these seems to be consistent reasons for the introduction of a harmonizing taxonomy, that may be useful to address the separation between legal, political, sociological, anthropological, and economic studies in this field. ${ }^{7}$ Moreover, this taxonomical approach, based upon an

6 The alternative study of institutional quality showed carried out by Prof. Martin Krause, Libertarian Network of Latin America and Libertad y Progreso Foundation (2013) is an example of this aim. This join study was conceived as an Index of Institutional Quality for Latin American countries.

7 The new tendency of providing quantitative training (econometrics and statistics) to lawyers and other social science scientist has not yet become a mainstream teaching approach for Latin American universities. Specifically, public universities 
understanding of law as those fundamental canons of justice upon which all free societies rest (Hayek, 1978), will oppose those scholars seduced by utilitarian economicism (Roemer, 1994; Posner, 1998) and therefore missing the exploration of the negative effects and danger of Legal Positivism (Ghersi, 2007). Incompressible, legal positivism is unconsciously used as the main supporter of aggregate concepts (legislation) in the study of institutions (Rojas, 2011). ${ }^{8}$ Consequently, the study of law as a spontaneous process is often forgotten and left aside without a strong signal of change by the mainstream law and economics literature (Ghersi, 2002). ${ }^{9}$

\section{Institutions and Civil Society}

A civil society can be defined as a group of interactions among individuals (Mendez, 2013b). ${ }^{10}$ This means it is a process (a dynamic structure), which is not consciously designed by anyone. It is highly complex, since it comprises a group of people with an infinite range of goals, tastes, values, and practical knowledge, and consists of human interactions (exchanges and dealings that often yield monetary prices and are always carried out according to certain rules, habits, or standards of conduct). All such human interactions are motivated by the force of entrepreneurship, which continually creates, discovers, and transmits information, as it adjusts and coordinates the contradictory plans of the different individuals through competition and enables them to coexist in

in countries like Peru, Ecuador, Bolivia and Paraguay openly reject to deep into a multidisciplinary training perspective.

8 There are also positions that still reject the use of quantitative methods for further development in social sciences. These positions involve an active minority, who describe contributions from the study of natural science as «inappropriate» (Rothbard, 1997; Huerta de Soto, 2010). However, as the target is to introduce a conceptual contribution, this paper does not adopt a methodological or «methodenstreit» approach.

${ }_{9}$ In recent years, contributions from Krause (2013), Rizzo (2011), Manne (2011), Rojas (2010), Ghersi (2009), Epstein (2006), Krecke (1998) and Cachanosky (1997) has represented an important output to start introducing changes to the conventional way to further study law and economics.

10 This group of interactions shows a «confluence process» of deliberate and spontaneous orders. 
an increasingly rich and complex environment (Foss et al., 2010; Manne, 2011).

In each category of civil society, these kinds of interactions are regulated through institutions (Hodgson, 2006). Thus, the legitimacy and dominance of these institutions will depend on the level of individual and collective acceptance and their ability to adapt to associative change (Caballero et al., 2005; Alonso et al., 2008). Consequently, the level of individual and collective acceptance may not be the same within each category of civil society. It may vary in relation to the degree of sustainability and organization of each specific kind of associative project. As civil societies are often dynamic categories, it is argued that the level of correlation cannot be accurately determined without analysing elements such as associative interaction and institutional coordination (Mendez, 2013a).

Furthermore, it is also essential to establish how strong institutional coordination is, in order to maintain an organized and competitive social fabric. Strong institutional coordination can impact positively on economic growth and performance, but can also have an effect/bearing on associative cohesion, dynamism and proactive «individual» (spontaneous) and «collective» (deliberated) interaction. Civil societies with a harmonious interaction between formal and informal institutions can be categorized as civil structured societies, as stated in previous research (Mendez, 2013c): «(...) Civil structured societies reflect an associative context where: Individuals can rapidly adapt themselves to their associative context (dynamic efficiency). (...) Civil societies show the interdependence between formal and informal rules that we have called institutional coordination or positive institutional interaction. It is understood as a complex human interaction involving interdependence and rejection after a certain level of institutional confrontation. The possibility of institutional rejection introduced the concept of associative or tacit abrogation and derogation of formal rules (Ghersi, 2007). Alternatively, when a civil society does not have a positive interdependence between formal and informal institutions, there emerges associative stagnation or institutional weakening, which refers to an elevated lack of institutional coordination or negative institutional interaction. 
In this associative context, individuals cannot adapt to associative change and manifest negative associative behaviour. We propose that the level of institutional weakening can be used as an indicator to describe a civil society's associative performance.»

The level of institutional weakening can be used to explore a civil society's performance. ${ }^{11}$ Following Levitsky et al. (2010), institutional weakening must be distinguished from «normal» institutional change. That is, institutional weakening should be seen as an accelerated institutional change (Pierson, 2000) and therefore as a disruption of institutional coordination. This is so because even though stronger rules evolve, they are vulnerable to being violated by agents who exert political power through «rent-seeking» behaviour that reflects «unproductive and destructive entrepreneurship» (Baumol, 1990).

Therefore, an institutional change in the framework of formal rules is not necessarily an indication of instability and institutional weakening (Helmke et al., 2004). Rather, the institutional weakening is shown as a setting or context in which structural problems are present as in: a) Exogenous shocks to civil society; b) Changes in political power; c) Changes in the distribution of preferences; and d) Other endogenous changes in the social fabric (North, 1990). This leads us to argue that institutional coordination can be weakened (as perceived by those on the «outside») as a consequence of the capture of the foundational framework (constitutional rules), that are supposed to structure the rule of law (Voigt, 2009). For example, Peru and Spain could be mentioned as particular case studies (for an unstructured and transitional civil societies respectively). The former has had sixteen different constitutions (Table 1) and the latter eight since the early nineteenth century (Table 2).

11 According to Levitsky et al. (2010): «(...) institutional strength can be conceptualized along two dimensions: imposition and stability. Imposition is the degree to which rules are enforced in practice. All relevant agents -in a given territoryroutinely complies with rules or face a high risk of punishment, imposition is high. By stability we mean durability; Institutions are stable to the extent that they survive not just the passing of time, but also changes in the conditions - power distributions and underlying preferences- under which they were established». 
TABLE 1

PERUVIAN CONSTITUTIONS 1812-1993

\begin{tabular}{|c|c|}
\hline Year & Constitution name \\
\hline 1812 & Political Constitution of the Spanish Royal Kingdom \\
\hline 1823 & Political Constitution of Peru \\
\hline 1826 & Political Constitution of the Peruvian Republic \\
\hline 1828 & Political Constitution of the Peruvian Republic \\
\hline 1834 & $\begin{array}{l}\text { Political Constitution of the Peru-Bolivian Confederation: Constitution of } \\
\text { the Republic of South Peru }\end{array}$ \\
\hline 1836 & $\begin{array}{l}\text { Political Constitution of the Peru-Bolivian Confederation: Constitution of } \\
\text { the Republic of North Peru }\end{array}$ \\
\hline 1836 & $\begin{array}{l}\text { Political Constitution of the Peru-Bolivian Confederation: Decree of } \\
\text { October 28, } 1836 \text { (Establishing the Peru-Bolivian Confederation) }\end{array}$ \\
\hline 1836 & $\begin{array}{l}\text { Political Constitution of the Peru-Bolivian Confederation: Foundational } \\
\text { Law of the Peru-Bolivian Confederation }\end{array}$ \\
\hline 1839 & Constitution of Peru \\
\hline 1856 & Constitution of the Republic of Peru \\
\hline 1860 & Constitution of Peru \\
\hline 1867 & Constitution of Peru \\
\hline 1920 & Constitution for the Republic of Peru \\
\hline 1933 & Constitution of Peru \\
\hline 1979 & Constitution of Peru \\
\hline 1993 & Constitution of Peru \\
\hline
\end{tabular}

Fuente: Congress of Peru (2014).

This is in contrast to Australia (potentially understood as an example of structured civil society). ${ }^{12}$ This country, less exposed

12 The selection of Australia (structured civil society), Spain (transitional civil society) and Peru (unstructured civil society) as examples does not refer to a tautological proposal. This selection was introduced, in part, focus on the following aspects: 1) rule of law (arbitrarily represented by the number of constitutions), 2) degree of trust in government, and 3) regulatory quality with data from the World Bank (2014 Worldwide Governance Indicators) and OECD's guiding principles for regulatory quality and performance (2005). For more details please refer to the following sections of the paper. 
TABLE 2

SPANISH CONSTITUTIONS 1812-1978

\begin{tabular}{ll}
$\frac{\frac{1}{1812}}{\frac{1834}{\frac{18}{1837}}} \frac{\text { Constitution name }}{\frac{\text { Political Constitution of the Spanish Royal Kingdom }}{\text { Royal Statute }}}$ \\
$\frac{\text { Spanish Constitution }}{\frac{1845}{1869}} \frac{\text { Spanish Constitution }}{\frac{\text { Spanish Constitution }}{1931}} \frac{\text { Spanish Constitution }}{\text { Spanish Constitution }}$ \\
\hline Spanish Constitution
\end{tabular}

Fuente: Congress of Deputies (2014).

to the capture of its foundational institutional framework, has had only one constitution (despite the changes in its governance arrangements, distributions of power, and preferences of the political elite, as stated by Shaw, 1983; Collins, 1985). ${ }^{13}$ Therefore, the framework of formal rules (constitutional or foundational) and institutional coordination in Peru and Spain can be considered less stable and weaker than those that govern Australian civil society. ${ }^{14}$

However, this preliminary exercise (a priori) to delineate some of the facts or conditions of institutional weakening and institutional coordination can also be reproduced by studying

13 This formal rule was approved in a series of referendums held over 1898-1900. The Commonwealth of Australia Constitution Act 1900 becomes law on $9^{\text {th }}$ July 1900. In the late '80s, the Australia Act 1986 removed the power of the United Kingdom parliament to change the Constitution. Since that, the Constitution can only be changed in accordance with a prescribed referendum procedure.

14 According to Williamson \& Kerekes (2011), legal and political constraints such as constitutions and electoral rules have to be classified as formal institutions as these rules show depth and durability, «but policies chosen by a dictator do not». In this regards, Latin American (Peru, Bolivia, Argentina and others.) and Continental European countries (Spain, Italy, and others.) represent an exception to this statement. From a legal approach it can be argued that Constitutions ruling these countries are actually an example of rules chosen by a dictator and approved trough restricted electoral procedures in political scenarios lacking of respect for democratic and individuals rights. 
the importance of an informal rules framework (O. Williamson, 2009; C. Williamson, 2009; and Mendez, 2013b). In this sense, the taxonomy of civil societies, as proposed in this paper, could be established as an instrument that would simplify theoretical research and the establishment of primary assumptions. It is hoped that this would encourage further studies (Mendez, 2011). These studies would examine certain aspects involving coordination processes and institutional weakening, and would try to integrate diverse approaches such as legal, economic, sociological, and / or anthropological ones (Mendez, 2013a). According to Levitsky et al. (2010) this is an important target as: «Recent studies on institutions (...) in the developing and post-communist world show that the institutions (...) vary widely along two dimensions: imposition and stability. This variation has important theoretical implications. Where agents do not expect institutions (...) to endure or the rules to be enforced, their behaviour will often differ markedly. Existing theories on the design and effects of institutions may well need to be refined if they are to be usefully applied to cases of institutional weakening. Treating institutional strength and/or weakening as a variable, rather than as an assumption that is taken for granted, recent studies have begun to refine institutional theories in ways that increase their usefulness in contexts where strong institutions (...) are the exception, not the rule (such as much of the developing world).» [Emphasis and italics added]

\section{Structured, Transitional and Unstructured Societies}

Therefore, this paper introduces a classification based on three new dynamic categories (summarized in table 3):

1) Structured Civil Society - characterized by high associative performance. In this type of civil society, associative interaction is harmonized and structured. Both formal and informal institutions are well coordinated (Mendez, 2013b). Informal institutions (rules) are the key mechanism for associative control to resolve associative conflicts (Domjahn, 2011; Dreyer et al., 2008); they also maximize the economic process and effec- 
TABLE 3

GENERAL ASPECT S OF STRUCTURED AND UNSTRUCTURED CIVIL SOCIETIES

\begin{tabular}{|c|c|}
\hline Structured Associative System & Unstructured Associative System \\
\hline $\begin{array}{l}\text { Individual is adapted to their } \\
\text { environment. }\end{array}$ & Small or no level of adaptation. \\
\hline $\begin{array}{l}\text { Associative interaction is coordinated } \\
\text { and structured. However, individual } \\
\text { goals and objectives are not completely } \\
\text { determined by the central planner. } \\
\text { Informal institutions (rules) are the } \\
\text { relevant mechanism for associative } \\
\text { control. }\end{array}$ & $\begin{array}{l}\text { Poor coordination, extreme associative } \\
\text { pluralism and fragmentation. }\end{array}$ \\
\hline $\begin{array}{l}\text { Values are spontaneously exchanged// } \\
\text { transmitted between individuals due to } \\
\text { associative interaction (based upon } \\
\text { individual alertness / entrepreneurship } \\
\text { function). }\end{array}$ & $\begin{array}{l}\text { The mechanisms of socializationlack } \\
\text { functionality. }\end{array}$ \\
\hline $\begin{array}{l}\text { Institutions are well-coordinated } \\
\text { mechanisms, effective at resolving } \\
\text { conflicts and contribute to the } \\
\text { maximization process of individuals. }\end{array}$ & $\begin{array}{l}\text { Problem-solving mechanisms } \\
\text { (institutions) are uncoordinated or } \\
\text { overwhelmed, unable to be effective. }\end{array}$ \\
\hline
\end{tabular}

Fuente: Own elaboration (2014).

tively develop the entrepreneurship function (Foss et al., 2010).

2) Transitional Civil Society - characterized by an associative performance that is becoming either stronger or weaker (Perez, 2001). This civil project lies between the categories of structured and unstructured because it suffers from a middle level of adaptation to associative change (Quian, 2003) and / or associative fragmentation.

3) Unstructured Civil Society - characterized by a poor associative performance. In this type of associative project, individuals show extremely poor adaptation to associative change; associative fragmentation is a strong impediment to the dynamic associative interaction between individuals. According to Alonso et al. (2008), there is a lack of functionality of the mechanisms for socialization, and institutions as problem-solving 
mechanisms are ineffective.In addition, if it refers to the primary system functions, it can be argued that this kind of associative project has issues with the following: a) Adaptation, whereby the social fabriccan neither adapt to its environment nor the environment to its needs; b) Ability to achieve goals as a social fabric; c) A lack of integration (that is, the system cannot regulate the interaction between its constituent parts nor control the ratio between the other three functional requirements); d) A notable problem with the latency or pattern maintenance because the system does not renew the motivation of individuals.

In unstructured civil societies, high levels of corruption among the bureaucracy and political agents help establish interpersonal relations where the illegal sector becomes more powerful. This scenario weakens civil societies' standards of productivity and exchange because the economic environment is not organized as formally as the government has encouraged. Thus, this negative interaction between the formal/legal and the informal/illegal also weakens the associative fabric and is reflected in higher transactional and associative costs.

In addition, the economic environment of an unstructured civil society introduces a set of complex associative scenarios (that is, it lacks dynamic efficiency), which are difficult to accurately describe. Also, the formal institutional framework narrowly regulates a smaller (formal) sector. The consequences of this new scenario are the generation of a more associative exclusion and a «potential» shortage of strong political governance.

Consequently, in an unstructured civil society, in order to measure welfare and make an efficient analysis, we need to incorporate several associative scenarios due to divisions in civil society. Finding a way out of these «negative scenarios» is a challenge that can only be undertaken through alternative «corporate forms» that express the prevalence of functional entrepreneurship. These alternative corporate forms cannot be regulated with a traditional bureaucratic approach; instead, a strategic deregulatory reform becomes the priority in the short-term in order to achieve institutional coordination (Mendez, 2013b). 
On one hand, a correlation between the suggested taxonomy of civil societies and the concept of positive institutional interaction or institutional coordination introduces the idea of community of interest, or economics as exchange of property rights. In this context, associative issues are not missing the associative fabric; rather, they depend upon positive and functional entrepreneurship and efficient associative interaction (organized by institutional coordination). A priori, it is argued that this can be measured through a basic index of access to welfare represented by legal stability or civic rationality (Mendez, 2012a; Mendez, 2013b; Mendez 2013c). ${ }^{15}$ Hence, in a context with strong civic rationality, functional entrepreneurship will indirectly induce strong political governance. In some way, and following Weber's approach (1964), the coordination problems affecting the social fabric are fixed by auto-generated institutions and other associative mechanisms. ${ }^{16}$

On the other hand, in an unstructured society, institutions representing political governance are weak (Caceres, 2005). Their institutional weakening opens doors to forms of power where clashes between associative groups (domination and associative cost transferences) are always present (Becker, 1983; Gerber, 1999). Therefore, it leads to a situation where political, economic and associative stability is a derivative of the struggle between groups, and so, any instance of associative cohesion is temporary in nature (Boron, 2003).

This conceptual taxonomy and theoretical illustration considers that individuals seek associative cohesion (dynamic equilibriums as described by Alonso et al. 2008), and are compelled to share links and generate different degrees of cooperation among individuals. This process can be illustrated by our proposal, demonstrating that positive interaction functions between formal and informal rules (De Soto et al., 1987). All this can be framed within a cultural and associative cohesion (Caceres, 2005). If this

15 This paper defines «legal stability» or «civic rationality» as causally efficient motivation for public-spirited action.

16 According to Weber's «Theory of Domination» (1964), it is possible to place the State as the first major concerned (for political and taxation purposes) in the consolidation of legal certainty and resource use in the law. 
process is added to the individual and group aspirations, it requires a degree of institutional stability, which is achieved to the extent that the functional entrepreneurship and the political and economic environment, point to a non-destructive competition context (Boettke et al., 2003). Also, in order to fulfil the conceptual illustration and taxonomy requirements, it is necessary to take into account the capabilities of the social fabric presented as a dynamic combination of human resources permanently engaged in cultural change and technological development (Caballero et al., 2005).

In addition, the taxonomy seeks to illustrate that without dynamic efficiency, limited (rational) political governance (Evans et al., 1999) and the contribution of functional entrepreneurship, institutional coordination cannot be achieved (Cobin, 2009). In this scenario, there will be a lack of associative cohesion and thus an unstructured civil society. Subsequently, the unproductive entrepreneurship (Baumol, 1996) manifested through mercantilist activities becomes an «institutionalized» activity (Ghersi, 1991). Consequently, this situation affects individual and group aspirations (which in an opposite scenario has to be harmoniously and accessibly organized or materialized by the "volk») and inhibits informal institutional arrangements from becoming formal arrangements, understood as stable and predictable associative instruments for organization and control (Mendez, 2013b). In this regard, it can be suggested that coordination among institutional arrangements cannot be seen as a supply or activity carried out only by formal government bodies (Blundell et al., 2000; Byrnes et al., 2001). Even in a traditional political scheme, governments are considered responsible for organizing the dynamics within the associative fabric. Following a similar approach, it can be stated that formal supply of rule of law or «Rechtsstaat» (e.g. a constitutional network, treaty, or code) cannot generate an institutional framework introducing a structured civil society. Therefore, the supply of formal institutional goods does not create its own demand and depends on an additional mixture of associative elements to reach the market equilibrium as it has been described by modern heterodox economic theory (Mendez, 2013b). 


\section{A Preliminary Attempt to Implement a Categorization of Civil Societies}

The aim of this study was to introduce a categorization of civil societies. Furthermore, the understanding of those categorizations will be an important instrument for classifying the degree of institutional weakening and coordination in any country in the world. For example, this classification can be used with the following countries: a) Australia is categorized as a structured civil society due to its relatively strong institutional framework (Kasper, 2003), as indicated by the 2013 World Value Survey, the 2007 Worldwide Governance Indicators, the 2013 Index of Economic Freedom, and the 2013 Index of Institutional Quality; b) Spain is categorized as a transitional civil society, due to its progressive institutional weakening as discussed by Aixala and Fabro (2008) and derived from the disaggregation of the 2013 Index of Institutional Quality, the 2013 World Economic Forum, and the 2013 Doing Business Index; and c) Peru is categorized as an unstructured civil society by relevant academic literature (Cavadias, 2001; Cordova, 2004; Caceres, 2007), as illustrated by the 2013 Index of Institutional Quality and the 2013 Latinobarometro Survey. ${ }^{17}$

These countries are categorized as such after taking into consideration: a) cultural aspects (Mendez, 2013); b) consistency between the theoretical trends developed by the taxonomy of civil societies and its empirical support; and c) other relevant exogenous and endogenous aspects. With regard to cultural aspects, all three countries are mainly western influenced. Therefore, a parallel in associative environment and individual interaction can be assumed. In addition, we need to accurately consider the similarities in cultural and ideological microclimates when addressing the underlying institutional framework (Grief, 1998). Therefore, our proposal differs from other more mainstream economic proposals, as sociological and historical aspects are not usually considered as part of the framework discussed in this paper (Hodgson, 2001). Concerning consistency between the theoretical trends, their current

17 Additional information in regards the selection of these countries was provided in the footnotes 12,23 and 14 . 
overall ranking on the indexes selected by this study is consistent with the sociological categorization introduced above (Mendez, 2011). Other relevant exogenous and endogenous aspects: the three countries' geographical location and their economic, associative, political, and international importance in their regional areas (Morcillo, 2011).

In addition, a further implementation of the suggested taxonomy will have to enclose other relevant aspects such as: a) Economic aspects; b) Political aspects; and c) Degree of power in the system of trust (trust in government and interpersonal trust) and the organizational or societal community rules, as these have traditionally been used to coordinate and facilitate the interaction between various components of society.

\section{$\mathrm{V}$ \\ CONCLUSIONS}

The categorization of civil societies as structured, transitional, or unstructured, can be a useful, general tool. Also, this study requires the use of more specific instruments, selected a priori, to measure the level of institutional weakening, institutional coordination, and other aspects. This taxonomy aims to illustrate that without dynamic efficiency, limited (rational) political governance and the contribution of functional entrepreneurship, institutional coordination cannot be achieved. Without these prerequisites, there will be a lack of associative cohesion and thus a civil unstructured society.

Even though interest in the introduction of empirical studies varies among professions (including associative scientists, lawyers, historians, anthropologists, and even sociologists), this alternative taxonomy aims to create a degree of integration among different programmes of research and methodenstreit approaches.

Categorizing civil societies as structured, transitional, and unstructured, will make case studies and traditional empirical analysis more accessible. However, in order to effectively achieve any of these tasks, core concepts such as institutional weakening and institutional coordination have to be considered. Further 
studies can also be introduced via the assessment of matching proxies such as interpersonal trust, institutional quality, perception of corruption, and the strengthening of property rights. Furthermore, an understanding of these categorizations will be an important instrument for classifying the degree of institutional weakening and coordination in any country in the world. An alternative taxonomy would work alongside further empirical studies to enhance the analysis of institutional coordination and comparative institutional analysis. In addition, whilst a conceptual contribution, an alternative taxonomy would represent a discernible point of departure, helping researchers to oversee and classify relevant variables affecting the economics of rules (Mendez, 2012) and, consequently, outcomes such as economic performance and growth.

\section{BIBLIOGRAPHICAL REFERENCES}

Alonso, J.A. (2012): «Crítica de Libro: Why Nations Fail. The origins of Power, Prosperity, and Poverty» (by Acemoglu, D. and Robinson, J.A.), Principios. Estudios de Economía Política, n. 21, Madrid: Fundación Sistema.

Alonso, J.A. and Garcimartin, C. (2008): Collective Action and Development. The Role of Institutions, Madrid: Editorial Complutense.

Alfonso, J. (1999): «Desarrollo económico: marco evolutivo e institucional», Ekonomiaz, vol. 43, pp. 232-250.

ArgoñA, A. (1991): «Values, Institutions and ethics», Working Paper, n.. 215, IESE Business School - University of Navarra Press.

ACEMOGLu, D. and Johnson, S. (2005): «Unbundling Institutions», Journal of Political Economy, vol. 113, n. 5, pp. 949-995.

Acemoglu, D. and Robinson, J.A. (2012): «Why Nations Fail», NY: Crown Publishers.

Ali, A. (2003): «Institutional Differences as Sources of Growth Differences», Atlantic Economic Journal, vol. 31, n.․․ 4, pp. 348-362. AOKI, M. (2001): Toward a Comparative Institutional Analysis, Cambridge - Mass: MIT Press.

- (2007): «Endogenizing Institutions and Institutional Changes», Journal of Institutional Economics, vol. 3, issue 1, pp. 1-31. 
AxAla, G. \& FABRO, J. (2008): « ¿El impacto de la calidad institucional sobre el crecimiento económico depende del nivel inicial de renta?», Economic Affairs, n.. 28, vol. 3, pp. 45-49.

BARRY, N. (1982 [1997]): «The tradition of Spontaneous Order», Laissez-Faire, n.. 6, pp. 1-43, UFM Press.

Bassanini, A., Scarpetta, S. and Hemmings, P. (2001): Economic growth: the role of policies and institutions. OECD Press.

BAUMOL, W. (1968): "Entrepreneurship in Economic Theory», American Economic Review, n. $\mathrm{0}$ 58, vol. 2, pp. 64-7.

BAUmOL, W.J. (1990): «Entrepreneurship: Productive, Unproductive, and Destructive», The Journal of Political Economy, vol. 98, n.. 5, pp. 893-921.

BECKER, G. (1983): «Una teoría de la Competencia entre grupos de presión por influencia política», Cuadernos Trimestrales de Economía, n. - 98, pp. 371-373.

BenEgAs-Lynch, A. (2005): «El Conocimiento y la Ciencia: Algunas Consideraciones Hayekianas». Revista de Economía y Derecho, vol. 2, n.․ 5, pp.13-26.

BLUNDELL, J. and RoBinson, C. (2000): «La regulación sin el Estado», Revista Libertas, n. 32, pp. 4-22.

BoetTKe, P.J. (2001): Calculation and Coordination Essays on Socialism and Transitional Political. London: Routledge.

- (2012): Living Economics. Yesterday, today and tomorrow, California: The Independent Institute.

Boettke, P.J. and Coyne, C.J. (2003): «Entrepreneurship and Development: Cause or consequence?», in Roger Koppl, Jack Birner, and Peter Kurrild-Klitgaard (ed.) Austrian Economics and Entrepreneurial Studies (Advances in Austrian Economics, Vol. 6), Emerald Group Publishing Limited, pp. 67-87.

BOLDEMAN, L. (2007): The cult of the market: economic fundamentalism and its discontents. Canberra: The Australian National University Press.

Boron, A. (2003): «Estado, Capitalismo y Democracia en América Latina». Colección Secretaria Ejecutiva CLACSO. Buenos Aires: Consejo Latinoamericano de Ciencias Sociales (Clacso).

Brennan, G. and BuchanAn, J. (1984): «Voter Choice: Evaluating Political Alternatives», American Behavioural Scientist, n.․․ 29, pp. 185-201. 
- (1987): La razón de las normas. Economía Política Constitucional, Madrid: Unión Editorial.

Buchanan, J. and Tullock, G. (1962): The Calculus of the Consense: Logical Foundations of Constitutional Democracy. Madrid: Planeta Press.

Byrnes, J., Dollery, B. and Wallis, J. (2001): Local Government Failure in Australia: An Empirical Analysis of New South Wales, NSW: University of New England School of Economics Publisher.

Caballero, G. (2001): «La Nueva Economía Institucional», Sistema Revista de Ciencias Sociales, Universidad de Vigo, n.ำ 161, pp. 59-86.

Caballero, G. and Kingston, C. (2005): «Cambio cultural, dinámica institucional y ciencia cognitiva: hacia una comprensión multidisciplinaria del desarrollo económico», Revista de Economía Institucional, n.. 13, vol. 13, pp. 100-121.

CÁCERES, R. (2005): Institutions, Law and Cost of Transaction. Lima: Pacific University Press.

Calabresi, G. and Melamed, A.D. (1972): «Property Rules, Liability Rules and Inalienability: One View of the Cathedral», Harvard Law Review, vol. 85, p. 108.

CAvadias, E. (2001): «El nuevo Institucionalismo en América Latina», Ciencias de Gobierno, n. . 10, pp. 11-25.

CHANG, H. (2011): "Institutions and economic development: theory, policy and history», Journal of Institutional Economics, vol. 7, n. 4 , pp. 473-498, Cambridge: Cambridge University Press.

Clemens, E. and CooK, J. (1999): «Politics and institutionalism: explaining durability and change», Annual Review of Sociology, n. ${ }^{\circ} 25$, pp. 441-66.

COASE, R.H. (1994): La empresa, el mercado y la ley. Madrid: Alianza Economía.

CoBin, J.M. (2009): Políticas públicas: tópicos modernos de la economía de mercado para el bienestar social, Santiago de Chile: Fondo Editorial Universidad Andrés Bello.

Collins, H. (1985): «Political Ideology in Australia: The Distinctiveness of a Benthamite Society», Daedalus, n.․ำ 1 vol. 114, pp. 147-169. 
Congress of Peru (2014): «Peruvian Political Constitutions», available at http:/ / www.leyes.congreso.gob.pe/constituciones. html.

Cordova, D. (2004): «La nueva economía institucional y el análisis del subdesarrollo en América Latina», Revista de Economía \& Derecho, n.․ 4, pp. 7-24.

De Soto, H., GHersi, E. and GHibellini, M. (1987): El otro sendero: La revolución informal, Lima: Instituto Libertad y Democracia.

DomJAHN, T. (2011): «Informal institutions and economic development», Erasmus Journal for Philosophy and Economics, vol. 5, issue 2.

Dreyer L., D. and BIE, L.H. (2008): «Informal Institutions and Intergenerational Contracts: Evidence from Schooling and Remittances in Rural Tanzania», Working Paper, n.ำ 3, Centre for Applied Microeconometrics, Copenhagen: Department of Economics University of Copenhagen.

EgGERTSSON, T. (1990): Economic Behaviour and Institutions, Cambridge: Cambridge University Press.

Esposto, A. and Tohme, F. (2009): Drifting Apart: The Divergent Development Paths of Argentina and Australia, VDM Verlag Publishers.

Evans, P. y RAUCH, R. (1999). «Bureaucracy and growth: a crossnational analysis of the effect of "Weberian" state structures on economic growth", American Sociological Review, n.․6, pp. 748-65.

Foss, N.J. and Klein, P.G. (2010): "Alertness, Action, and the Antecedents of Entrepreneurship», The Journal of Private Enterprise, vol. 2, pp. 145-164.

FuRUBOtB, E.G. and Richter, R. (1998): Institutions and Economic Theo$r y$, The Contribution of the New Institutional Economics, Michigan: The University of Michigan Press.

GAGLIARDI, F. (2008): «Institutions and Economic Change: A Critical Survey of the New Institutional Approaches and Empirical Evidence», Journal of Socio-Economics, vol. 37, n. ${ }^{\circ}$ 1, pp. 416-443. Garcia-Guadilla, M. and Roa Carrero, P. (1997). «Civil Society, Classic Liberal Democracy and Market Economics: The Liberal Organizations in Venezuela», Estudios Científicos, Salamanca: Ediciones USAL. 
Gerber, E.R. (1999): The Populist Paradox: Interest Group Influence and the Promise of Direct Legislation, Princeton: Princeton University Press.

Ghersi, S.E. (1988). «El Costo de la Legalidad», Centro de Estudios Públicos, n. 30 , pp. 83-110.

- (1991): «Economía de la corrupción», Centro de Estudios Públicos, n.. 73, pp. 3-20.

- (2005): «La economía informal en América Latina», Cato Journal, vol. 7 , n.․ 1 , pp. 1-14.

- (2007): «The competitive character of the Sources of Law», Revista de Instituciones, Ideas y Mercados, n.․ 47, pp. 89-109.

- (2009): «Las consecuencias jurídicas del mercantilismo», $E L$ CATO, Washington: Cato Institute.

GERBER, E.R. (1999): The Populist Paradox: Interest Group Influence and the Promise of Direct Legislation, Princeton: Princeton University Press.

GreIF, A. (1998): «Historical and Comparative Institutional Analysis», The American Economic Review, n. ㅇ 88, vol. 2, pp. 80-84.

Greif, A. and Laitin, D.D. (2004): "A Theory of Endogenous Institutional Change», American Political Science Review, n.․98, pp. 613-32.

HART, H.L.A. (1980): El concepto de Derecho, México: Editorial Nacional.

HAYEK, F.A. (1948): Individualism and Economic Order, University of Chicago Press.

- (1964): The Counter-Revolution of Science: Studies on the abuse of reason, The Free Press of Glencoe Collier-Macmillan Limited, London.

- (1978): Law, Legislation and Liberty, University of Chicago Press.

Hellman, J. and KaufmanN, D. (2001): «La captura del Estado en las economías en transición», Finanzas y Desarrollo, n. ํㅜ 38, vol. 3, pp. 31-35.

Helmke, G. and Levitsky, S. (2004): «Informal Institutions and Comparative Politics: A Research Agenda», Perspectives on Politics, vol. 2, n. ${ }^{\circ} 4$.

Heyne, P.T, Prychitko, D.L. and BoettKe, P.J. (2009): The Economic Way of Thinking, Prentice Hall. 
Hirshman, A.O. (1986): Interés privado y acción pública, F.C.E. México.

Hodgson, G.M. (1993): Economía y evolución: Revitalizando la Economía. Madrid: Colegio de Economistas de Madrid, Celeste Ediciones.

- (1998): «The Approach of Institutional Economics». Journal of Economic Literature, vol. 36, pp. 166-192.

- (2001): How Economics Forgot History: The Problem of Historical Specificity in Social Science, London: Routledge.

- (2006): What are institutions?, Journal of Economic Issues, vol. 40, n.․ 1 .

Huerta De Soto, J. (2010): Socialism, Economic Calculation and Entrepreneurship, Cheltenham: Edward Elgar Publishing.

KASPER, W. (2003): Building Prosperity: Australia's future as a global player, Sydney: The Centre for Independent Studies.

Kelsen, H. (2001): Introducción a la Teoría Pura del Derecho. Lima: Asociación Peruana de Derecho Constitucional.

KIRZNer, I.M. (1976): «Equilibrium versus Market Process», The Foundations of Modern Austrian Economics, Kansas City: Sheed and Ward Inc.

- (1978a): Competition and Entrepreneurship, University of Chicago Press.

- (1978b): Economics and Error, Kansas City: Sheed Andrews and McMeel.

Klein, P.G., Mahoney, J.T., Mcgahan, A. and Pitelis, C. (2010): «Toward a theory of public entrepreneurship», European Management Review, n. ${ }^{\circ}$ 07, pp. 1-15. Milano: European Academy of Management.

Krause, M. (2007): Calidad de las instituciones y competencia institucional, Londres: International Policy Network.

Krause, M., Barbeito, A. \& Resico, M. (2006): «¿Qué instituciones se necesitan para un crecimiento equitativo y sustentable?», Revista Valores, n.. 67, pp. 20-32.

KRECKE, E. (1998): «El Derecho y el orden del mercado: una crítica austriaca al análisis económico del Derecho», Thémis Nueva Época, n.o 38, pp. 244-264.

KUCZYNSKI, P.P. and WilliAmson, J. (2003): After the Washington Consensus: stimulating growth and reforms in Latin America, Institute for International Economics. Lima: UPC Publisher. 
KuHN, T.S. (1971): La estructura de las revoluciones científicas, México D.F.: Fondo de Cultura Económica.

Levitsky, S. and Murillo, M.V. (2010): «Variacion en la fortaleza institucional», Revista de Sociologia, n. 24, pp. 31-56.

Méndez Reategui, R.C.B. (2011): «Institutional Innovation, Deregulation and Competition in a Structured Society», HDR Expo 2011, Sydney: Macquarie University Faculty of Business and Economics Press.

- (2013a): «Entrepreneurship, Institutions in a Changing Environment», URJC and IJM - VI Austrian Economics Conference. Madrid: Instituto Juan de Mariana.

- (2013b). «An Introduction to Institutional Coordination», (Working Paper) GLEA Conference, Free University of Bolzano.

- (2013c): «An Introduction to Institutional Coordination as An Alternate Model for Neo-Institutional Economic Analysis», Procesos de Mercado, Revista Europea de Economía Política, vol. 10, n.․ 2, pp. 151-200.

Menger, C. (1976 [1871]): Principles of Economics, Institute for Humane Studies.

Molteni, G. (2006): «Principales aportes de la Nueva Economía Institucional (NEI) y sus críticos», Revista Valores, n.ำ 67, pp. 8-19.

Morcillo, J. (2011): Una crisis marcada por la globalización: Intervención, desregulación y autorregulación regulada, AEDPA: Universidad Castilla-La Mancha.

Mueller, D.C. (1983): The Political Economy of Growth. New Haven: Yale University Press.

- (1986): «Rational Egoism Versus Adaptive Egoism as Fundamental Postulate for a Descriptive Theory of Human Behaviour», Public Choice, n.o 51, pp. 3-23.

NorTH, D. (1981): Growth and Structural Change, New York: W.W. Norton.

- (1990): Institutions, Institutional Change and Economic Performance, Cambridge: Cambridge University Press.

- (1991): «Institutions», Journal of Economic Perspectives, vol. 5, n. ${ }^{\circ} 1$, pp. $97-112$.

- (1994). «Economic Performance Through Time», American Economic Review, vol. 84, n. 3, pp. 359-368. 
- (2005): Understanding the Process of Economic Change, New York: Princeton University Press.

Ostrom, E. (1990): Governing the Commons: The Evolution of Institutions for Collective Action, Cambridge: Cambridge University Press.

OECD (2005): OECD Guiding Principles for Regulatory Quality and Performance, available at http://www.oecd.org/fr/ reformereg/34976533.pdf.

PARK, S.M. (2012). Empirical analysis of Informal Institutions, Thesis Dissertation 1180, Marburg: Philipps-Universität Marburg.

PARSONS, T. (1966): «El sistema social». Revista de Occidente, Buenos Aires: Paidós.

- (1967): Ensayos de Teoría Sociológica, Buenos Aires: Paidós.

- (1968 [1937]): La estructura de la acción social: estudio de teoría social con referencia a un grupo de recientes escritores europeos, Barcelona: Ediciones Guadarrama.

- (1974): La sociedad: Perspectivas evolutivas y comparativas, México: Trillas.

- (1978): El sistema de las sociedades modernas, México: Trillas

Pierson, P. (2000): «The limits of institutional design: explaining institutional origins and change», Governance, vol. 4, n.․ 13, pp. 475-99.

PÉREZ, E. (2001): Transitions (Theories of): changes in the Eastern countries, Madrid: Editora Crítica de Ciencias Sociales.

QUIAN, Y. (2003): «How reform worked in China», In Search of prosperity», D. Rodrik (Ed.) Analytic narratives on economic growth, Princeton: Princeton University Press.

San Emeterio, N. (2006): New Institutional Economics, Madrid: Síntesis Press.

Schotter, A. (1981): The Economic Theory of Social Institutions, Cambridge: Cambridge University Press.

SoBEL, R.S. (2008): «Testing Baumol: Institutional quality and the productivity of entrepreneurship", Journal of Business Venturing 23, pp. 641-655.

Stiglen, G. (1982): The Economist as Preacher, and Other Essays, Chicago: University of Chicago Press.

- (1992): «Law or Economics?», Journal of Law and Economics, n..$^{\circ}$ 35, pp. 455-68. 
SHAw, A.G.L. (1983): The Story of Australia, London: Farber and Farber.

Spanish Congress of Deputies (2014): «Spanish Constitutions 1812-1978», available at http:/ / www.congreso.es/portal/page / portal/Congreso/Congreso/Hist_Normas/ConstEsp1812_ 1978.

VoIGT, S. (2009): «How to Measure the Rule of Law», available at SSRN: http:/ / ssrn.com/abstract=1420287 or http:/ / dx.doi.org/ 10.2139 /ssrn.1420287

Weber, M. (1930): The Protestant Ethic and the Spirit of Capitalism, London: Allen \& Unwin.

- (1964): Economía y Sociedad, vol. 1, p. 632, México: Fondo de Cultura Económica.

Williamson, C. (2009): «Informal institutions rule: institutional arrangements and economic performance», Public Choice, n. ${ }^{-}$ 139, pp. 371-387.

Williamson, O. (1985): The Economic Institutions of Capitalism: Firms, Markets, Relational Contracting, New York: Free Press.

WORLD BANK (2014): Worldwide Governance Indicators, available at http:/ /info.worldbank.org/governance/wgi/index.aspx\#faq 
